\title{
Motive Element in Planed Murder Criminal Act According to Article 340 KUHP
}

\author{
Lalu Irawadi ${ }^{1}$, Rodliyah, Muhammad Natsir ${ }^{2}$ \\ ${ }^{1}$ Master of Law students, Faculty of Law, Mataram University, Indonesia \\ ${ }^{2}$ Lecturer Faculty of Law, Mataram University, Indonesia
}

\begin{abstract}
This research is conducted to find out and analyse the implementation of criminal law in motive element of planed murder perpetrator as well as to find out and analyse the vindication of motive of planed murder perpetrator by applying normative legal research method. Aimed to analyze the implementation of positive law norms under statute, case and historical, comparative and conceptual approach. Research result shown that implementation of Article 340 KUHP depends on judge's point of view poured in his legal considerations. The point of view can be Monistic where motive is not a significance consideration as long as the crime lead to certain legal consequences or dualistic where motive is important to consider in order to determine perpetrator's grade of guilt (psychologically) since dualistis point of view differentiate between objective element and subjective element (guilt element). To proof that there is motive element in a planed murder, Judge shall apply vindication principle used in Indonesia's criminal law procedure according to Article 184 KUHP and law number 48 of 2009 concerning judiciary power
\end{abstract}

Keywords: Motive element, planed murder

\section{Introduction}

The difference between a murder and a planned murder is that if the murder referred to in Article 338 of the Criminal Code is carried out immediately when the intention arises, while the planned murder is suspended after the intention arises, regulate have "motives" and careful planning to kill the victims.

In Article 340 of the Criminal Code it states that "Anyone who intentionally and with prior plan seizes the lives of others, is threatened because of murder with a plan, with capital punishment or life imprisonment or for a specified period of twenty years"1

In Article 340 of the Criminal Code the motive is not required. Motive is only one element, it is only one ingredient. The motive is in the intention of the perpetrator to commit a crime, all acts start from the motive, therefore the motive needs to be explored to determine intentionality. So if there is no motive there will be no intention, and if there is no motive there is no crime, the objective is here.

The motive must be relevant to the act, because the motive can be uncertain The description above says that Article 340 of the Criminal Code is not required to have a motive. Well, the word "not required" does not mean that it does not need a motive, the motive is still needed. Why motives are still needed, because motives are an inseparable part of the intention or state of mind when actions result in loss of life. In addition, Article 340 of the Criminal Code requires motives because Article 340 of the Criminal Code is a material offense, where the consequences arising from intentional acts are prohibited. The motive is a must in Article 340 of the Criminal Code, because Article 340 of the Criminal Code is one of the dolus / opzet / intentional acts. So it must be proven how intentionally with the planning carried out by the perpetrators. Another reason that makes Article 340 of the Criminal Code requires motives is because the acts regulated in Article 340 of the Criminal Code contain the threat of a sentence of up to the death penalty to life imprisonment. 
The act done intentionally certainly has a motive or reason as to why the perpetrators of the act of planning take the lives of others. It is illogical in law if someone commits murder including premeditated murder without a clear motive. From the grammatical interpretation of Article 340 of the Criminal Code it is certain that Article 340 of the Criminal Code requires motives in addition to using grammatical interpretation also requires legal logic in interpreting Article 340 of the Criminal Code. Therefore requires caution in its application because of the threat of a very heavy sentence, capital punishment to life imprisonment.

Article 340 of the Criminal Code has elements, First; Element on purpose. this first element requires the elaboration of its intentions. What is the main motive so that the act done intentionally is done, because it is impossible for someone to commit premeditated murder (material action), especially by using poison without a clear motive. Second. Elements with advance planning. This element requires that the planning process be elaborated.

Crimes against lives in the Criminal Code contained in chapter XIX with the title "crimes against the lives of people" regulated in Articles 338 to $350^{2}$. In this study focused on the provisions of Article 340 of the Criminal Code which reads: "Anyone who deliberately and with prior plans to take lives other people, threatened with murder with a plan, with capital punishment or life imprisonment or for a specified period of time, a maximum of twenty years".

The provisions of this Article raise academic issues. The most urgent is whether the motives in the Article need to be proven or not. Then comes the theoretical debate and the practical debate in law enforcement over the Article. So it is not surprising that legal academics and legal practitioners often debate it. At least we can read from a variety of literature and see in the debate of legal academics in various print and electronic media as an example in the case of the abundance of Jesica Kumala Wongso as the perpetrators of the planned murder of Mirna as stipulated in Article 340 of the Criminal Code. In the trial, the legal experts were presented by the Public Prosecutor as well as by legal advisors from Jesica Kumala Wongso to ask for academic confirmation regarding criminal liability, including asking whether information needed to prove a motive element or not to prove that the accused had committed premeditated murder or not . As a result the experts presented at the trial turned out to differ in view too.

Opinions that agree must be expressed motives or need to be proven in Article 340 of the Criminal Code is Masrukin Ruba'i. Masrukin Ruba'i, ${ }^{3}$ the 'intentional' element in Article 340 of the Criminal Code departs from motives, intentions, and actions. The planned murder, said the lecturer at the Faculty of Law, Brawijaya University Malang, on Thursday (9/22) yesterday, took time, that is, the time from intention until the criminal act was committed. So, there are stages of planning for committing a crime.

Prof. Eddy O. S. Hiariej stressed that the motive did not need to be evidenced in Article 340 of the Criminal Code. Article 340 is dolus premeditatus which states three important things in premeditated murder as regulated in Article 340 of the Criminal Code. First, the offender when deciding the will to do in a calm state. Second, there is sufficient time between deciding the will and carrying out the action. Third is the implementation of actions carried out in a calm state. By looking at the history of the formation of Article 340 of the Criminal Code, Eddy quoted the view of Jan Remmelink, a professor and former Dutch Attorney General, that the motive was kept away from the formulation of offense. Remmelink writes that the makers of Article 340 of the Dutch Penal Code put the motives of the perpetrators as far as possible outside the formulation of offense if the motives remain to be sought, then the motives are only in lightening or aggravating matters. ${ }^{4}$

\section{Research Methods}

This research will be prepared using the type of normative juridical research, which is research focused on examining the application of the rules or norms in positive law ${ }^{5}$. Normative research can also be called doctrinal research which in essence is research conducted by examining library materials or legal documents consisting of primary legal materials, secondary legal materials and tertiary legal materials.

\footnotetext{
${ }^{2}$ Leden Marpaung, Tindak Pidana Terhadap Nyawa dan Tubuh cet. Ke-3, Jakarta: Sinar Grafika, 2005, p. 19

${ }^{3} \mathrm{https}$ //www.hukumonline.com/berita/baca/lt57e4aaf2730e6/pro-kontra-motif-dalam-kasus-pembunuhan-berencana. Accessed September 13, 2019

${ }^{4}$ http://www.monitorday.com/detail/40069/ahli-hukum-pidana-jelaskan-soal-pasal- pembunuhan-berencana-tak-perlumotif, accessed September 15, 2019.

5 Johnny Ibrahim,Teori dan Metodologi Penelitian Hukum Normatif, Bayumedia Publishing, Malang,2006, p. 295.
} 
The problem approach method used in this study is the Statute Approach, an approach carried out by examining all laws and regulations relating to legal issues being faced, especially Article 340 of the Criminal Code ${ }^{6}$. Conceptual Approach, this approach becomes important because the understanding of the views/doctrines that develop in the science of law can be a foothold to build legal arguments when resolving legal issues. Case Approach, Case approach is an approach that is carried out by examining cases related to the issues at hand that have become court decisions that have permanent legal force.

The sources and types of legal materials used in this study are as follows. Primary legal materials are legal materials that have binding legal force ${ }^{7}$. The primary legal materials used in this study are the Criminal Procedure Code, the Criminal Procedure Code and the Jurisprudence. Secondary legal materials that provide an explanation of primary legal materials, including legal literature literature books, scientific work from the legal community, as well as other materials related to the problems in this study. Tertiary legal material is material that provides instructions and explanations for primary legal materials and secondary legal materials such as dictionaries, encyclopedias and cumulative indices.

The sources and types of legal materials used in this study are as follows. Primary legal materials are legal materials that have binding legal force. The primary legal materials used in this study are the Criminal Procedure Code, the Criminal Procedure Code and the Jurisprudence. Secondary legal materials that provide an explanation of primary legal materials, including legal literature literature books, scientific work from the legal community, as well as other materials related to the problems in this study. Tertiary legal material is material that provides instructions and explanations for primary legal materials and secondary legal materials such as dictionaries, encyclopedias and cumulative indices.

All legal materials obtained and collected are then processed, and then analyzed with the teleological interpretation method, namely: searching for the purpose or purpose of the legislation. Furthermore deductive conclusions are drawn, namely examining legal material relating to the formulation of Article 340 of the Criminal Code and then conclusions are drawn. general conclusion.

\section{Results and Discussion}

\section{Legal Basis and Elements of Planned Murder}

In Criminal law there are various elements. To find out the existence of a criminal offense, then generally formulated in criminal legislation concerning acts that are prohibited and accompanied by sanctions. In this formulation, several elements or conditions which are characteristic of the prohibition are determined so that they can clearly be distinguished from other acts that are not prohibited. ${ }^{8}$

Therefore it is necessary for the researcher to convey the elements of criminal acts based on the doctrine of criminal law according to experts, namely ${ }^{9}$ :
a. Behavior and consequences (deeds)
b. Matters or circumstances that accompany the action
c. Additional circumstances that incriminate the criminal
d. against objective law
e. Elements against the law are subjective

Regarding the element of "whosoever" some criminal law experts argue that "whosoever" is not an element but only to show that the offender is human. However, this opinion is refuted by other experts by expressing the opinion that "whoever" is true is an element, but it needs to be elaborated on who is the person and how many people. So the identity of "who is it" must be clear. The ambiguity of the identity of the offender can cancel the indictment. That is why it is considered an element ${ }^{10}$.

In each formulation of the Criminal Code Articles and criminal acts, the element (bestitelen) "whosoever" is an important word in viewing criminal errors and accountability. As a word "whosoever" it requires a fairly serious study of the principles of guilt and criminal liability in an evidentiary effort. But in an effort to

${ }^{6}$ Peter Mahmud Marzuki, Penelitian Hukum, Edisi Pertama Cetakan ke-4 Kencana Prenada Media Group, , Jakarta, 2008, p.93.

${ }^{7}$ Soerjono Soekanto, Pengantar Penelitian Hukum, Jakarta: Universitas Indonesia (UI-Press),Jakarta, 2007, p. 52

8 Unsur-unsut tindak pidana, http://pusathukum.blogspot.com/2015/10/unsur-unsur-tindak-pidana.html accessed September 17, 2019

${ }^{9}$ Andi Hamzah. Bunga Rampai Hukum Pidana dan Acara Pidana. Ghalia Indonesia Jakarta. 2001.p. 30

${ }^{10}$ Leden Marpuang, Asas Teori Praktek Hukum Pidana cet ke-6, Jakarta: Sinar Grafika, 2009,p.9. 
prove, the element "who/every person" does not necessarily directly refer to individuals (naturalijk persoon). When reviewing the Indonesian Criminal Code (KUHP) which is considered a subject of criminal law is only an individual in a natural biological connotation (naturlijkee person). In addition, the Criminal Code still adheres to the principle of "sociates delinquere non potest" in which a legal entity or corporation is deemed unable to commit a crime.

Thus, we can pay attention to the basic concepts in the field of criminal law, so there are 3 main problems, namely what actions are categorized as criminal acts, what mistakes can be accounted for in general, what criminal sanctions should be imposed on the defendant. In this way, the "whosoever/every person" element is a person who if the person is proven to have complied with the criminal acts charged against the defendant. The element "who/every person" cannot be addressed to the defendant because determining this element is not enough by connecting the defendant as an individual person or a legal subject proposed as a defendant in this case, but what is meant by every person in the law is people whose actions have been validly and convincingly proven to meet all elements of a criminal offense.

So to prove the element "who/every person" must be proven first other elements. Therefore the element "who/every person" still depends on other elements. If the elements have been fulfilled then the element "who/everyone" refers to the defendant, but vice versa if the other elements are not fulfilled then the element "who / everyone" is not fulfilled as well.

Thus in practice that often happens where the element "who/everyone" as often in the letter of demand and in the judge's decision directly points to the defendant without seeing the theories that have been submitted indeed raises legal issues. ${ }^{11}$

From the description above, the element of whoever in Article 340 of the Criminal Code refers to legal subjects, namely humans (natural persons) not legal entities (recht persons). Reviewing whoever is in the formulation of offense means that the discussion of legal subjects that can be considered as subjects is human, meaning "Naturelijke personnel" while animals and their bodies cannot be considered as subjects. ${ }^{12}$

The elements of premeditated murder are as follows: Subjective elements, which are intentional and premeditated. The objective element of action takes away the life and object of the lives of others. ${ }^{13}$

The criminal act of murder constitutes a material criminal act or material delict, which is a criminal act which can only be considered as completed by the perpetrators with the emergence of a prohibited or undesirable result of the law. Thus, one cannot speak of a murder crime, if the consequences of the death of another person have not yet arisen.

From the above description in general Article 340 of the Criminal Code has a simplified element of two kinds, namely subjective elements and objective elements. What is meant by subjective elements are the elements that are inherent in the offender or related to the offender, and include in it everything that is contained in his heart.

While what is meant by objective elements are elements that have to do with conditions, that is, in situations where the actions of the offender must be carried out. The subjective elements of a crime are:

1. Deliberate or accidental (dolus or culpa)

2. Intent or (voornemen)

3. Types of intent or (oogmerk)

4. Planning in advance or (voorbedache raad)

5. Feelings of fear or (vress) ${ }^{14}$

The objective elements of a crime are :

1. The nature of breaking the law or wederrechtelijkheid

2. The quality of the doer

3. Causality, namely the relationship between an action as a cause and a reality of cause and effect The crime of murder as regulated in Article 340 of the Criminal Code contains the following elements: a. On purpose b. And planned in advance c. Eliminating the lives of others.

11 Musri Nauli, Unsur "barang siapa" Dalam Tindak Pidana http://musri-nauli.blogspot.com/ 2012/07/unsur-barangsiapa-dalam-tindak-pidana.html accessed on 2 April 2019

${ }^{12}$ Azhar Hafid, Kajian Hukum Tentang Pembunuhan Berencana Menurut Pasal 340 KUHP, Lex Crimen Vol. IV/No. 4/Juni/2015.p. 88

13 Adami Chazawi, Kejahatan Terhadap Tubuh \& Nyawa, Jakarta: PT. Raja Grafindo Persada, 2013, p. 81.

14 Tri Lestari Ningsih, Pembuktian Tindak Pidana Pembunuhan (Tinjauan Yuridis Putusan Nomor : 26/Pid.Sus/A/2013/PN.Pbg) Universitas Jenderal Soedirman Fakultas Hukum Purwokerto 2014,p. 54 
According to R.Susilo ${ }^{15}$ that the criminal act of premeditated murder is a premeditated murder, it can be said that this is an ordinary murder (dooslag) in Article 338 of the Criminal Code but carried out with a prior plan "premeditated" (voobedochterade) that is between the emergence of the intent to kill with the execution is still a tempo for the maker to calmly think for example by the way how the murder will be carried out, this tempo should not be done too narrowly but also it should not be too long, the important thing is whether within that tempo the maker can calmly think about it which actually he still had a chance to cancel his intention to kill, but he did not use, murder by using poison is almost all a "moord" because of course there must be a plan in advance.

Regarding the elements of premeditated murder, Anwar divided it into two, namely: a. The objective element: eliminate one's soul, by first planned b. Subjective element: deliberate and planned.

From the description of Article 340 of the Criminal Code above, the researcher can state that Article 340 of the Criminal Code contains the contents that there must be loss of life, planned, existence and mistakes of the perpetrators. Related to motives or drivers, there must be intention. Planned intentions, meaning intentions appear first, plans in a state of calm and implementation in a state of calm as well.

2. Judge's Basic Considerations in Applying the Motive Element for the Criminal Act of Planned Murder under Article 340 of the Indonesian Criminal Code

A judge in convicting a criminal may not convict a criminal unless with at least two legal instruments, so that the judge obtains the conviction that a crime actually happened and the defendant is guilty of doing it (Article 183 of the Criminal Procedure Code). The intended legal evidence is: (a). Witness Statement; (b). Expert Statement; (c). Letter; (d). Hints; (e). Defendant's statements or matters that are generally known so do not need to be proven (Article 184). ${ }^{16}$

Therefore, the two valid evidences referred to in Article 183 of the Criminal Procedure Code are a minimum of two out of five valid evidences based on Article 184 of the Criminal Procedure Code. For example the witness's evidence and the defendant's evidence or the defendant's letter and statement evidence.

The judicial process is part of an effort to seek justice and in order to ensure legal certainty for all citizens who are subject to the provisions of the law and applicable laws and regulations. In the realm of criminal law a series of acts that attack the safety of body and soul are seen as a form of action that is threatened by crime because it is deemed to meet the element of offense as mandated by the applicable laws. The series of examinations at the level of investigation, investigation, prosecution and prosecution in the Court is an integral part of law enforcement efforts in the context of proving legal facts at the trial (judex factie). ${ }^{17}$

Judge's consideration is one of the most important aspects in determining the realization of the value of a judge's decision that contains justice (ex aequo et bono) and contains legal certainty, in addition it also contains benefits for the parties concerned so that the judge's consideration must be addressed carefully, both , and careful. If the judge's judgment is not thorough, good, and accurate, then the judge's decision derived from the judge's consideration will be overturned by the High Court / Supreme Court ${ }^{18}$.

The judge's decision is the climax of a case that is being examined and tried by a judge. The judge gives his decision regarding the following matters:

1) Decision regarding the event, whether the defendant has committed the alleged crime to him.

2) Decision regarding the law, whether the act committed by the defendant is a criminal offense and whether the defendant is guilty and can be convicted.

3) Decision concerning the criminal, if the defendant can indeed be convicted. ${ }^{19}$

3. The application of sanctions Article 340 of the Criminal Code Relates to the Motive Element for the Criminal Act of Planned Murder

${ }^{15}$ R. Susilo.Pembelajaran Lengkap Hukum Pidana (Sistem Tanya Jawab). Bandung : Politeia.1981.p. 145

16 Satjipto Rahardjo. Bunga Rampai Permasalahan Dalam Sistem Peradilan Pidana. Pusat Pelayanan Keadilan dan Pengabdian Hukum Jakarta. 1998. hlm. 11. Lihat dalam http://digilib.unila.ac.id/14268/12/BAB\%20II.pdf accessed 6 April 2019.

${ }^{17}$ Thaufik Amirullah dkk, Pertimbangan Hukum Hakim Dalam Memutus Perkara Pembunuhan Berencana dengan Motif Persembahan Upacara Adat oleh Suku Noaulu Maluku Tengah (Studi Terhadap Putusan Nomor 87/Pid.B/2005/PN.Msh dan Putusan Nomor 25/PID/2006/PT. MAL) jurnal (online tanpa taun dan penerbit).p.6

${ }_{18}$ Mukti Arto, Praktek Perkara Perdata pada Pengadilan Agama, cet V (Yogyakarta, Pustaka Pelajar, 2004), p.140

19 Sudarto. Hukum dan Hukum Pidana. Alumni. Bandung. 1986. Hlm 74 . Lihat dalam http://digilib.unila.ac.id/5337/8/BAB\%20II.pdf accessed 8 April 2019. 
In applying Article 340 of the Criminal Code the Judge must pay attention to the following provisions:

a. Legal Aggravating Circumstances, namely criminal weighting factors regulated in the law, consisting of additional circumstances that incriminate the criminal formulated as an element of a criminal offense; As Moeljatno's opinion, that "additional circumstances which incriminate the criminal" is one of the elements or elements of the criminal act; Criminal ballast formulated in statutory regulations;

b. Judicial Aggravating Circumstances, namely incriminating circumstances whose judgment is the authority of the court. ${ }^{20}$

Furthermore, whether the motive element needs to be proven or not depends on the judge's perspective in its legal considerations and the judge's perspective to determine the elements of a criminal offense. In criminal law there are two views about the element of a criminal offense, namely:

1. Monistic Opinion. Monistic view is a view that sees conditions, for a crime must include two things namely nature and conduct. This view provides the principles of understanding, that in the sense of an act / a crime has already been included in a prohibited act (criminal act) and criminal responsibility / error (criminal responbility).

2. Dualistic Opinion, In contrast to the monistic view which sees the entire condition of a criminal being attached to a criminal act, the dualistic view separates the criminal act from the criminal liability. According to the monistic view in the sense of a crime already included in it both criminal act and criminal responsibility, while according to the dualistic view, namely in a criminal act only included criminal act, and criminal responsibility is not an element of crime. Therefore, to declare an act as a criminal offense is sufficient by having an act formulated by a law which has an unlawful nature without a justification. ${ }^{21}$

Amir Ilyas $^{22}$ then concluded that there was a difference between monistic and dualistic schools, where monistic flow included elements of criminal responsibility into elements of criminal acts. While the dualistic element separates the elements of criminal offense and elements of criminal liability, in this case the writer is more inclined towards dualistic flow because there is a weakness in the monistic flow in terms of the inclusion of criminal acts. One example in the event of persuasion where if someone persuades another person who is incompetent to commit a crime where. Based on the monistic theory if the act occurs, then it can not automatically be said to be a criminal offense because one of the elements of a criminal act according to the monistic flow is not fulfilled so that the person who is persuading cannot be said to "persuade to commit a crime" of course such things can be utilized by people certain to commit crimes that make him free from criminal threats.

This is different when viewed from the dualistic theory in which the dualistic theory separates criminal liability and criminal offenses, so that those who are incompetent will still be considered to have committed crimes even though they will later be released for reasons of forgiveness to themselves but those who persuade can still be said to "persuade committing a crime "because in the dualistic theory does not include the skill element as an element of the criminal act, as previously explained and therefore the actions of the person who is not capable in the dualistic theory remain a criminal offense.

In other words, if according to the opinion and judgment of the court, the defendant has been legally and convincingly proven to have made a mistake in the form of a criminal offense charged to him in accordance with the evidentiary system and the principle of proof of the minimum limit of evidence specified in Article 183 of the Criminal Procedure Code, the accused's guilt has been sufficiently proven by at least two legitimate pieces of evidence that gave the judge confidence, the defendant was the criminal. ${ }^{23}$

20 Dwi Hananta, Pertimbangan Keadaan-Keadaan Meringankan Dan Memberatkan Dalam Penjatuhan Pidana (Aggravating And Mitigating Circumstances Consideration On Sentencing), Jurnal Hukum Dan Peradilan (Online), Volume 7, Nomor 1 Maret 2018,p. 92

${ }^{21}$ Amir ilyas ,asas-asas hukum pidana memahami tindak pidana dan pertanggungjawaban pidana sebagai syarat pemidanaan (disertai teori-teori pengantar dan beberapa komentar), Diterbitkan atas kerja sama Rangkang Education Yogyakarta \& PuKAP-Indonesia, 2012,p. 38

22 Ibid, p. 44-45

${ }^{23}$ Yahya Harahap. 2009. Pembahasan Permasalahan Dan Penerapan KUHAP (Pemeriksaan Sidang Pengadilan, Banding, Kasasi, dan PK). Jakarta: Sinar Grafika hlm 354. Lihat dalam ARIF Mulyana Kurniawan, Penerapan Pasal 197 Ayat (1) Huruf K Kitab Undangundang Hukum Acara Pidana (Studi Putusan Perkara Korupsi Susno Duadji No: 899/K/Pid.Sus/2012). Kementerian Pendidikan Dan Kebudayaan Universitas Jenderal Soedirman Fakultas Hukum Purwokerto 2014, p. 13 
The explanation is the Act that meets the formulation of the law, namely the first element of a criminal offense is the act or act of someone. This person's deeds are a connecting point and basis for criminal giving. This act includes doing or not doing. Furthermore, it is against the law, which is one element of a criminal act is an element of unlawful nature. This element is an objective evaluation of actions not of the maker. According to Sudarto, an act is said to be against the law if: If the act is included in the formulation of offense as formulated in the law.

Then the culprit is able to take responsibility. According to Chairul Huda that the basis for a criminal act is the principle of legality, while the maker can be convicted on the basis of a mistake, this means that a person will have criminal liability if he has committed wrongdoing and is against the law. Basically criminal liability is a form of mechanism created to react to violations of certain agreed-upon acts. ${ }^{24}$

The element of error is the main element in criminal liability. In the definition of a criminal act, it does not include a matter of criminal liability, the criminal act only refers to whether the act is against the law or prohibited by law, whether a person committing the crime is later convicted depending on whether someone committing the crime has an element of error or not . Criminal accountability in the comman law system is always associated with mens rea dam punishment (punishment).

Criminal responsibility has a relationship with the community that is the responsibility relationship with the community as a function, the function here is that the responsibility has criminal impeachment power so that accountability here has a social control function so that in society there is no crime. ${ }^{25}$

Thus according to the researcher, it is proven that whether the defendant violated Article 340 of the Criminal Code depends on the judge using a viewpoint which is monistic or dualistic. Because both can be accepted as a form of freedom and independence of judicial authority. Nevertheless taking into account the provisions of Article 183 of the Criminal Procedure Code and Article 184 of the Criminal Procedure Code.

Therefore, in the application of Article 340 of the Criminal Code depends on the Judge's perspective in its legal considerations. When using positive studies, it is not important to know the motives (monistic opinion), but if with a dualistic view, the motives are important to know to determine the gradation of the perpetrator's mistakes (psychological), because dualism separates the objective element from the subjective element (the error element).

\section{Conclusion}

The application of Article 340 of the Criminal Code depends on the Judge's perspective in its legal considerations. First, the Monistic view, it is not important to find and know the important motive for killing there is the legal consequences imposed. Second, if the dualistic view is important motives to know to determine the gradation of the perpetrator's mistakes (psychological), because dualism separates the objective element from the subjective element (the error element).

To prove whether there is an element of motives for the perpetrators of premeditated murder (Article 340 of the Criminal Code) the Judge must use the principle of proof adopted in the Indonesian criminal procedure system, which is in accordance with Article 183, Article 184 of the Criminal Code and Law Number 48 of 2009 concerning Judicial Power .

\section{References}

[1] Adami Chazawi, Kejahatan Terhadap Tubuh \& Nyawa, Jakarta: PT. Raja Grafindo Persada, 2013.

[2] Amir ilyas, asas-asas hukum pidana memahami tindak pidana dan pertanggungjawaban pidana sebagai syarat pemidanaan (disertai teori-teori pengantar dan beberapa komentar), Diterbitkan atas kerja sama Rangkang Education Yogyakarta \& PuKAP-Indonesia, 2012.

[3] Andi Hamzah. Bunga Rampai Hukum Pidana dan Acara Pidana. Ghalia Indonesia Jakarta. 2001.

[4] Article 340 of the Criminal Code

[5] Azhar Hafid, Kajian Hukum Tentang Pembunuhan Berencana Menurut Pasal 340 KUHP, Lex Crimen Vol. IV/No. 4/Juni/2015.

${ }^{24}$ Chairul Huda, Dari Tindak Pidana Tanpa Kesalahan Menuju Kepada Tiada Pertanggung jawab Pidana Tanpa Kesalahan, Cetakan ke-2, Jakarta, Kencana, 2006, p.68

${ }^{25} \mathrm{http} / / /$ repository.umy.ac.id/bitstream/handle/123456789/12507/G.\%20BAB\%203.pdf?sequence=5\&isAllowed=y accessed April 8, 2019 
[6] Chairul Huda, Dari Tindak Pidana Tanpa Kesalahan Menuju Kepada Tiada Pertanggung jawab Pidana Tanpa Kesalahan, Cetakan ke-2, Jakarta, Kencana, 2006.

[7] Dwi Hananta, Pertimbangan Keadaan-Keadaan Meringankan Dan Memberatkan Dalam Penjatuhan Pidana (Aggravating And Mitigating Circumstances Consideration On Sentencing), Jurnal Hukum Dan Peradilan (Online), Volume 7, Nomor 1 Maret 2018.

[8] Johnny Ibrahim,Teori dan Metodologi Penelitian Hukum Normatif, Bayumedia Publishing, Malang,2006.

[9] Leden Marpaung, Tindak Pidana Terhadap Nyawa dan Tubuh cet. Ke-3, Jakarta: Sinar Grafika, 2005.

[10] Leden Marpuang, Asas Teori Praktek Hukum Pidana cet ke-6, Jakarta: Sinar Grafika, 2009.

[11] Mukti Arto, Praktek Perkara Perdata pada Pengadilan Agama, cet V (Yogyakarta, Pustaka Pelajar, 2004).

[12] Peter Mahmud Marzuki, Penelitian Hukum, Edisi Pertama Cetakan ke-4 Kencana Prenada Media Group, , Jakarta, 2008.

[13] R. Susilo.Pembelajaran Lengkap Hukum Pidana (Sistem Tanya Jawab). Bandung : Politeia.1981.

[14] Soerjono Soekanto, Pengantar Penelitian Hukum, Jakarta: Universitas Indonesia (UI-Press),Jakarta, 2007.

[15] Thaufik Amirullah dkk, Pertimbangan Hukum Hakim Dalam Memutus Perkara Pembunuhan Berencana dengan Motif Persembahan Upacara Adat oleh Suku Noaulu Maluku Tengah (Studi Terhadap Putusan Nomor 87/Pid.B/2005/PN.Msh dan Putusan Nomor 25/PID/2006/PT. MAL) jurnal (online tanpa taun dan penerbit).

[16] Tri Lestari Ningsih, Pembuktian Tindak Pidana Pembunuhan (Tinjauan Yuridis Putusan Nomor : 26/Pid.Sus/A/2013/PN.Pbg) Universitas Jenderal Soedirman Fakultas Hukum Purwokerto 2014.

[17] Yahya Harahap. 2009. Pembahasan Permasalahan Dan Penerapan KUHAP (Pemeriksaan Sidang Pengadilan, Banding, Kasasi, dan PK). Jakarta: Sinar Grafika hlm 354. Lihat dalam ARIF Mulyana Kurniawan, Penerapan Pasal 197 Ayat (1) Huruf K Kitab Undang-undang Hukum Acara Pidana (Studi Putusan Perkara Korupsi Susno Duadji No: 899/K/Pid.Sus/2012). Kementerian Pendidikan Dan Kebudayaan Universitas Jenderal Soedirman Fakultas Hukum Purwokerto 2014.

[18] https://www.hukumonline.com/berita/baca/lt57e4aaf2730e6/pro-kontra-motif-dalam-kasuspembunuhan-berencana. Accessed September 13, 2019

[19] http://www.monitorday.com/detail/40069/ahli-hukum-pidana-jelaskan-soal-pasal- pembunuhanberencana-tak-perlu-motif, accessed September 15, 2019.

http://pusathukum.blogspot.com/2015/10/unsur-unsur-tindak-pidana.html accessed September 17, 2019

[20] Musri Nauli, Unsur "barang siapa" Dalam Tindak Pidana_http://musri-nauli.blogspot.com/ 2012/07/unsur-barang-siapa-dalam-tindak-pidana.html accessed on 2 April 2019

[21] Satjipto Rahardjo. Bunga Rampai Permasalahan Dalam Sistem Peradilan Pidana. Pusat Pelayanan Keadilan dan Pengabdian Hukum Jakarta. 1998. hlm. 11. Lihat dalam http://digilib.unila.ac.id/14268/12/BAB\%20II.pdf accessed 6 April 2019.

[22] Sudarto. Hukum dan Hukum Pidana. Alumni. Bandung. 1986. Hlm 74. Lihat dalam http://digilib.unila.ac.id/5337/8/BAB\%20II.pdf accessed 8 April 2019.

[23] http://repository.umy.ac.id/bitstream/handle/123456789/12507/G.\%20BAB\%203.pdf?sequence=5\&i sAllowed=y accessed April 8, 2019 